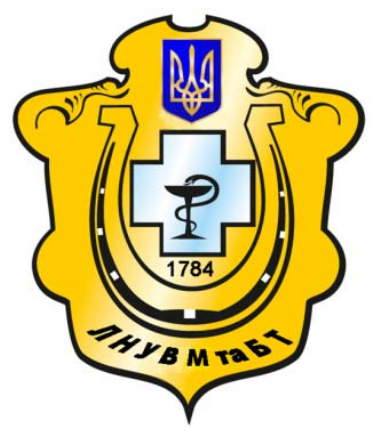

Науковий вісник Львівського національного університету ветеринарної медицини та біотехнологій імені С.З. Гжицького

Scientific Messenger of Lviv National University of Veterinary Medicine and Biotechnologies named after S.Z. Gzhytskyj

doi:10.15421/nvlvet7728

ISSN 2518-7554 print

ISSN 2518-1327 online

$\underline{\text { http://nvlvet.com.ua/ }}$

УДК 636:636.087.8

\title{
Антимікробна активність нового комбінованого антибактеріального препарату на основі флуорфеніколу та доксицикліну
}

\author{
Т.І. Стецько ${ }^{1}$, В.П. Музика ${ }^{1}$, Л.Л. Островська ${ }^{1}$, В.І. Буцяк ${ }^{2}$ \\ stetskot@ukr.net,viktormuzyka@gmail.com,ostrovskalora@gmail.com,v.butsyak@gmail.com \\ ${ }^{1}$ Державний науково-дослідний контрольний інститут ветеринарних препаратів та кормових добавок, \\ вул. Донецька, 11, м. Львів, 79019, Україна; \\ ${ }^{2}$ Львівський національний університет ветеринарної медицини та біотехнологій імені С.3. Гюсицького, \\ вул. Пекарська, 50, м. Львів, 79010, Україна
}

\begin{abstract}
Бактеріальні інфекції незаразного характеру є одними з найпоширеніших захворювань серед сільськогосподарських тварин та птииі. Часто етіологічним фактором захворювання є асочіація мікроорганізмів. У такому разі актуальним стає питання впровадження в клінічну практику антибактеріальних препаратів із широким спектром антимікробноі активності, яка б охоплювала якнайбільше мікроорганізмів, збудників бактеріальних інфекиій. Одним з прийнятних і доиільних методів, який би підвищував ефективність хіміотерапії бактеріальних інфекиій, є раціональне застосування поєднань антимікробних речовин. У статті наведені результати дослідження антимікробної активності новоствореного комбінованого антибактеріального препарату на основі синтетичного антибіотика флуорфеніколу із групи феніколів та доксииикліну - антибіотика, щуо належить до групи тетрациклінів. Рівень бактеріостатичної активності комбінованого препарату порівнювали з бактеріостатичною активністю монопрепаратів, діючими речовинами яких є окремо флуорфенікол і доксициклін. Визначали мінімальні інгібуючі концентрації (МІК) комбінованого препарату і монопрепаратів для грампозитивних та грамнегативних бактерій, таких як Staphylococcus aureus, Streptococcus suis, Bordetella bronchiseptica, Escherichia coli i Salmonella pullorum, виділених з біологічного матеріалу, відібраного від хворих на різні бактеріальні захворювання свиней та курчат-бройлерів. Отримані результати вказують на те, щзо флуорфенікол і доксициклін у комбінованому препараті діють індиферентно відносно до виділених штамів Staphylococcus aureus, Streptococcus suis ma Escherichia coli, коли кожен антибіотик у комбінаиії проявляе незалежну дію на мікроорганізм, не відмінну за активністю від їх роздільного застосування. Водночас діючі речовини комбінованого препарату проявляють певну синергічну дію відносно до виділених штамів Bordetella bronchiseptica ma Salmonella pullorum, що проявляється підвищенням активності поєднання антибактеріальних сполук порівняно з сумою їх незалежних ефектів за рахунок зростання активності одного або обох з активно діючих компонентів препарату.
\end{abstract}

Ключові слова: фармакологія, антимікробна активність, флуорфенікол, доксициклін, бактеріостатична активність, комбінований препарат.

\section{Антимикробная активность нового комбинированного препарата на основе флуорфеникола и доксициклина}

Т.І. Стецко, В.П. Музыка, Л.Л. Островская, В.І. Буцяк

stetskot@ukr.net, viktormuzyka@gmail.com,ostrovskalora@gmail.com,v.butsyak@gmail.com

${ }^{I}$ Государственный научно-исследовательский контрольный институт ветеринарных препаратов и кормовых добавок, ул. Донечкая, г. Львов, 79019, Украина;

${ }^{2}$ Львовский национальный университет ветеринарной медиџины и биотехнологий имени С.3. Гжицкого, ул. Пекарская, 50, г. Львов, 79010, Украина

Citation:

Stetsko, T.I., Muzyka, V.P., Ostrovska, L.L., Butsyak, V.I. (2017). Antimicrobial activity of new combined antibacterial drug based on florfenicol and doxycycline. Scientific Messenger LNUVMBT named after S.Z. Gzhytskyj, 19(77), 125-130. 
Бактериальные инфекции незаразного характера являются одними из самых распространенных заболеваний среди сельскохозяйственных животных и птицы. Этиологическим фактором заболевания является ассоциация микроорганизмов. В таком случае актуальным становится вопрос внедрения в клиническую практику антибактериальных препаратов иирокого спектра антибактериальной активности, которая бы охватьвала наибольшее количество микроорганизмов, возбудителей бактериальных инфекиий. Одним из приемлемых и целесообразных методов, который повышал бы эффективность химиотерапии бактериальных инфекций, является рациональное применение сочетаний антимикробных вещеетв. В статье представлень результаты изучения антимикробной активности нового комбинированного антибактериального препарата на основе синтетического антибиотика флуорфеникола из группы фениколов и доксициклина - антибиотика, принадлежащего к группе тетрациклинов. Уровень бактериостатической активности комбинированного препарата сравнивали з бактериостатической активностью монопрепаратов, действующими веществами которых являются отдельно флуорфеникол и доксициклин. Определяли минимальные ингибируюшие концентрации (МИк) комбинированного препарата и монопрепаратов для грамположительных и грамотрицательных бактерий, таких как Staphyloсоссиs аигеия, Streptococcus suis, Bordetella bronchiseptica, Escherichia coli и Salmonella pullorum, выделенных из биоматериала, отобранного от больных различными бактериальными заболеваниями свиней и изыплят-бройлеров. Полученные результаты показали, что флуорфеникол и доксициклин в комбинированном препарате действуют индиферентно по отношению к выделенным штаммам Staphylococcus aureus, Streptococcus suis ma Escherichia coli, когда каждый антибиотик в комбинации проявляет независимое действие на микроорганизм, не отличное по активности от их раздельного применения. В то же время действуюшие вещества комбинированного препарата проявляют некоторое синергическое действие по отношению к вылеленным штаммам Bordetella bronchiseptica и Salmonella pullorum, что проявляется увеличением активности сочетания антибактериальных соединений по сравнению с суммой их независимых эффектов за счет активности одного или обоих из активно действуюших компонентов препарата.

Ключевые слова: антимикробная активность, флуорфеникол, доксициклин, бактериостатическая активность, комбинированный препарат.

\title{
Antimicrobial activity of new combined antibacterial drug based on florfenicol and doxycycline
}

\author{
T.I. Stetsko ${ }^{1}$, V.P. Muzyka ${ }^{1}$, L.L. Ostrovska ${ }^{1}$, V.I. Butsyak ${ }^{2}$ \\ stetskot@ukr.net, viktormuzyka@gmail.com, ostrovskalora@gmail.com,v.butsyak@gmail.com \\ ${ }^{1}$ State Scientific Research Control Institute of veterinary preparations and feed additives, \\ Donetska Str., 11, Lviv, 79019, Ukraine; \\ ${ }^{2}$ Lviv National University of Veterinary Medicine and Biotechnologies named after S.Z. Gzhytskyi, \\ Pekarska Str., 50, Lviv, 79010, Ukraine
}

\begin{abstract}
Bacterial infections of noncontagious character is one of the most common diseases among livestock and poultry. Often an association of microorganisms is etiological factor for these diseases. In this case, actual is an introduction into clinical practice antibiotics with a broad spectrum of antimicrobial activity, which would cover the most microorganisms, causative agents of bacterial infections. One of appropriate and suitable methods that would increased the effectiveness of chemotherapy of bacterial infections is a rational use of a combination of antimicrobial agents. In the article the results of the study of antimicrobial activity of new combined antibacterial preparation, based on synthetic antibiotic florfenicol from the group amfenicols and doxycycline from the group of tetracyclines, are given. The level of bacteriostatic activity of the combination drug was compared with bacteriostatic activity of monopreparations, active ingredients in ones are separately florfenicol and doxycycline. Were determined the minimum inhibitory concentration (MIC) of the combined drug and monopreparations for gram-positive and gram-negative bacteria such as Staphylococcus aureus, Streptococcus suis, Bordetella bronchiseptica, Escherichia coli and Salmonella pullorum, isolated from biological material, took from pigs and broiler chickens with various bacterial diseases. The results showed that florfenicol and doxycycline in combined preparation act indifferently regarding isolates Staphylococcus aureus, Streptococcus suis and Escherichia coli, when every antibiotic in an combination demonstrates independent action on the organism, not different activity at their separate application. At the same time, the active ingredients of the combined drug showed a synergistic effect against the isolated strains Bordetella bronchiseptica and Salmonella pullorum, demonstrated by increasing the activity of the combination of antibacterial compounds compared to the sum of their independent effects by increasing the activity of one or both of active drug
\end{abstract} components.

Key words: antimicrobial activity, florfenicol, doxycycline, bacteriostatic activity, combined preparation.

\section{Ветуп}

Недоліком застосування монопрепаратів за лікування тварин $з$ незаразними захворюваннями бактеріальної етіології є низька терапевтична ефективність, оскільки вони впливають лише на певний мікроорганізм. А до того ж не на всю асоціацію, що призводить до хронізації патологічного процесу, який у подальшому не піддається лікуванню. Крім того, досі відсутня виражена протимікробна дія на мікрофлору за асоційованих бактеріозів. Одним із прийнятних і до- цільних методів, який би підвищував ефективність хіміотерапії бактеріальних інфекцій та уповільнював розвиток резистентності у мікроорганізмів, є раціональне застосування сукупного поєднання антимікробних речовин (Stetsko, 2008).

Використання комбінованої хіміотерапії розраховане на максимально можливе охоплення потенційних збудників захворювання і на досягнення бактерицидного ефекту, оскільки за важкого інфекційного процесу захисні сили організму ослаблені і не можуть впо- 
ратися з бактеріостатично пригніченими мікроорганізмами (Kovalev, 1983).

Дія антимікробних препаратів відносно мікроорганізмів відбувається на клітинному або молекулярному рівні та проявляється у вигляді антагоністичного, індиферентного, адитивного і синергічного ефектів. У разі антагонізму ефект від використання поєднання антибактеріальних сполук нижчий, ніж від будь-якого з них, взятого окремо. Індиференція являє собою незалежну дію кожного інгредієнта комбінації на мікроорганізм, не відмінну за ефективністю від їх роздільного застосування. За адитивної дії фармакологічний ефект від застосування сукупного поєднання препаратів еквівалентний сумі ефектів при їх роздільному використанні.

Під синергізмом мають на увазі підвищення активності за сукупного поєднання антибактеріальних сполук порівняно з сумою їх незалежних ефектів (Stetsko, 2008). Класичним прикладом синергізму є спільне застосування сульфаніламідів та триметоприму. Подібність механізму дії та фармакологічних властивостей діючих речовин (швидке всмоктування через слизову оболонку травного тракту, тривала терапевтична концентрація у крові та тканинах тварин, приблизно однакова швидкість виведення з організму), а також оптимальне їх співвідношення (4 : 1) дозволило збільшити силу антимікробної дії препарату в 4-6 разів порівняно $з$ первинними компонентами (Indiveri and Hirsh, 1986; Stetsko, 2005).

Мета роботи - порівняти антимікробну активність нового комбінованого антибактеріального препарату на основі флорфеніколу та доксицикліну 3 активністю монопрепаратів із аналогічними діючими речовинами відносно до мікроорганізмів, збудників бактеріальних інфекцій у свиней та свійської птиці.

\section{Матеріал і методи досліджень}

Дослідження проводили на польових штамах мікроорганізмів, виділених 3 біологічного матеріалу (кров, носові виділення, калові маси, гній із абсцесу), відібраного від свиней та курчат-бройлерів. До того ж виділено та ідентифіковано такі мікроорганізми: Staphylococcus aureus, Streptococcus suis, Bordetella bronchiseptica, Escherichia coli, Salmonella pullorum. Виділення та ідентифікацію проводили за загальновизнаними мікробіологічними методиками (Golovko et al., 2007). Рівень бактеріостатичної активності препарату встановлювали шляхом визначення мінімальної інгібуючої концентрації (МІК) його діючої основи для бактерій-ізолятів. МІК препарату встановлювали методом серійних розведень у рідкому живильному середовищі (Metodychni vkazivky, 2008). Рівень бактеріостатичної активності комбінованого препарату порівнювали з бактеріостатичної активності монопрепаратів, діючими речовинами яких є окремо флуорфенікол і доксициклін.

Отримані значення мінімальних інгібуючих концентрацій антибіотиків інтерпретували згідно 3 Performance Standards for Antimicrobial Disk and Dilution Susceptibility Tests for Bacteria Isolated from Animals. Значення МIK флуорфеніколу інтерпретували таким чином: МІК $\leq 2$ мкг/мл - штам мікроорганізму чутливий; МІК 2-8 мкг/мл - помірно чутливий; MIК $\geq 8$ мкг/Мл - резистентний. Значення МІК доксицикліну інтерпретували так: МІК $\leq 2$ мкг/мл - штам мікроорганізму чутливий; МІК 2-8 мкг/мл - помірно чутливий; МІК $\geq 8$ мкг/Мл - резистентний.

\section{Результати та їх обговорення}

Рівень бактеріостатичної активності досліджуваних препаратів для бактерій-ізолятів наведений у таблицях 1-5.

Таблиия 1

МІК досліджуваних препаратів для ізоляту Staphylococcus aureus

\begin{tabular}{|c|c|c|c|c|c|}
\hline \multicolumn{2}{|c|}{ Комбінований препарат } & \multicolumn{2}{|c|}{ Монопрепарат (флуорфенікол) } & \multicolumn{2}{|c|}{ Монопрепарат (доксициклін) } \\
\hline $\begin{array}{c}\text { Розведення, } \\
\text { мкг/мл }\end{array}$ & Наявність росту & $\begin{array}{c}\text { Розведення, } \\
\text { мкг/мл }\end{array}$ & Наявність росту & $\begin{array}{c}\text { Розведення, } \\
\text { мкг/мл }\end{array}$ & Наявність росту \\
\hline 150 & - & 100 & - & 200 & 一 \\
\hline 75 & - & 50 & - & 100 & - \\
\hline 37,5 & - & 25 & - & 50 & - \\
\hline 18,7 & - & 12,5 & - & 25 & - \\
\hline 9,3 & - & 6,2 & - & 12,5 & - \\
\hline 4,7 & + & 3,1 & - & 6,2 & - \\
\hline 2,4 & + & 1,6 & + & 3,1 & + \\
\hline 1,2 & + & 0,8 & + & 1,6 & + \\
\hline 0,6 & + & 0,4 & + & 0,8 & + \\
\hline 0,3 & + & 0,2 & + & 0,4 & + \\
\hline 0,15 & + & 0,1 & + & 0,2 & + \\
\hline
\end{tabular}

Примітка: «+»- наявність росту; «一»- відсутність росту

Отримане значення МІК комбінованого препарату для Staphylococcus aureus становить 9,3 мкг/мл. Оскільки співвідношення флуорфеніколу до доксицикліну в препараті становить $1: 2$, то відповідно очікуване значення МІК флуорфеніколу становить 3,1 мкг/мл, а МІК доксицикліну - 6,2 мкг/мл. Рівень бактеріостати- чної активності монопрепарату на основі флуорфеніколу для ізоляту Staphylococcus aureus становить 3,1 мкг/мл, а монопрепарату на основі доксицикліну 6,2 мкг/мл.

Отримані результати вказують на те, що існує помірна чутливість стафілококу до усіх препаратів. Су- 
дячи зі значень мінімальної інгібуючої концентрації, діючі речовини комбінованого препарату проявляють індиферентну дію відносно до виділеного штаму Staphylococcus aureus, коли кожен антибіотик у комбінації проявляє незалежну дію на мікроорганізм, не відмінну за активністю від їх роздільного застосування.

Значення МІК препарату для Streptococcus suis становить 4,7 мкг/мл. Рівень бактеріостатичної активності монопрепарату на основі флуорфеніколу для ізоляту Streptococcus suis становить 1,6 мкг/мл, а монопрепарату на основі доксицикліну - 3,1 мкг/мл.
Після отримання значення МІК комбінованого препарату стрептокок виявився чутливим до флуорфеніколу і помірно чутливим до доксицикліну. Чутливим виявився ізолят Streptococcus suis до монопрепарату на основі флуорфеніколу і помірно чутливим до монопрепарату на основі доксицикліну. Флуорфенікол і доксициклін у комбінованому препараті проявляють індиферентну дію відносно до виділеного штаму Streptococcus suis.

МІК досліджуваних препаратів для ізоляту Streptococcus suis

\begin{tabular}{|c|c|c|c|c|c|}
\hline \multicolumn{2}{|c|}{ Комбінований препарат } & \multicolumn{2}{|c|}{ Монопрепарат (флуорфенікол) } & \multicolumn{2}{|c|}{ Монопрепарат (доксициклін) } \\
\hline $\begin{array}{c}\text { Розведення, } \\
\text { мкг/мЛ }\end{array}$ & Наявність росту & $\begin{array}{c}\text { Розведення, } \\
\text { мкг/мл }\end{array}$ & $\begin{array}{c}\text { Наявність } \\
\text { росту }\end{array}$ & $\begin{array}{c}\text { Розведення, } \\
\text { мкг/мл }\end{array}$ & Наявність росту \\
\hline 150 & - & 100 & - & 200 & - \\
\hline 75 & - & 50 & - & 100 & - \\
\hline 37,5 & - & 25 & - & 50 & - \\
\hline 18,7 & - & 12,5 & - & 25 & - \\
\hline 9,3 & - & 6,2 & - & 12,5 & - \\
\hline 4,7 & - & 3,1 & - & 6,2 & - \\
\hline 2,4 & + & 1,6 & - & 3,1 & - \\
\hline 1,2 & + & 0,8 & + & 1,6 & + \\
\hline 0,6 & + & 0,4 & + & 0,8 & + \\
\hline 0,3 & + & 0,2 & + & 0,4 & + \\
\hline 0,15 & + & 0,1 & + & 0,2 & + \\
\hline
\end{tabular}

Примітка: «+»- наявність росту; «一»- відсутність росту

Таблицяя 3

МІК досліджуваних препаратів для ізоляту Bordetella bronchiseptica

\begin{tabular}{|c|c|c|c|c|c|}
\hline \multicolumn{2}{|c|}{ Комбінований препарат } & \multicolumn{2}{|c|}{ Монопрепарат (флуорфенікол) } & \multicolumn{2}{|c|}{ Монопрепарат (доксициклін) } \\
\hline $\begin{array}{c}\text { Розведення, } \\
\text { мкг/мл }\end{array}$ & Наявність росту & $\begin{array}{c}\text { Розведення, } \\
\text { мкг/мл }\end{array}$ & Наявність росту & $\begin{array}{c}\text { Розведення, } \\
\text { мкг/мл }\end{array}$ & Наявність росту \\
\hline 150 & - & 100 & - & 200 & - \\
\hline 75 & - & 50 & - & 100 & - \\
\hline 37,5 & - & 25 & - & 50 & - \\
\hline 18,7 & - & 12,5 & - & 25 & - \\
\hline 9,3 & - & 6,2 & - & 12,5 & - \\
\hline 4,7 & - & 3,1 & - & 6,2 & - \\
\hline 2,4 & - & 1,6 & - & 3,1 & - \\
\hline 1,2 & + & 0,8 & - & 1,6 & + \\
\hline 0,6 & + & 0,4 & + & 0,8 & + \\
\hline 0,3 & + & 0,2 & + & 0,4 & + \\
\hline 0,15 & + & 0,1 & + & 0,2 & + \\
\hline
\end{tabular}

Примітка: «+»- наявність росту; «一»- відсутність росту

Значення МІК комбінованого препарату для Bordetella bronchiseptica становить 2,4 мкг/мл. За отриманим значенням МІК комбінованого препарату Bordetella bronchiseptica виявилася чутливою як до флуорфеніколу, так і до доксицикліну. Рівень бактеріостатичної активності монопрепарату на основі флуорфеніколу для ізоляту Bordetella bronchiseptica становив 0,8 мкг/мл, а монопрепарату на основі доксицикліну - 3,1 мкг/мл.

Судячи з отриманих значень мінімальної інгібуючої концентрації діючі речовини комбінованого препарату проявляють певну синергічну дію, що проявляється підвищенням активності поєднання антибактеріальних сполук порівняно з сумою їх незалежних ефектів за рахунок збільшення активності доксицикліну відносно до виділеного штаму Bordetella bronchiseptica.

Значення МІК комбінованого препарату для Escherichia coli становить 9,3 мкг/мл. Значення МІК монопрепарату на основі флуорфеніколу становить 3,1 мкг/мл, а монопрепарату на основі доксицикліну 6,2 мкг/мл. Результати вказують про помірну чутливість виділеного штаму кишкової палички до всіх препаратів. Згідно з отриманими значеннями мінімальної інгібуючої концентрації діючі речовини комбінованого препарату проявляють індиферентну дію відносно до ізоляту Escherichia coli. 
Таблиия 4

МІК досліджуваних препаратів для ізоляту Escherichia coli

\begin{tabular}{|c|c|c|c|c|c|}
\hline \multicolumn{2}{|c|}{ Комбінований препарат } & \multicolumn{2}{|c|}{ Монопрепарат (флуорфенікол) } & \multicolumn{2}{c|}{ Монопрепарат (доксициклін) } \\
\hline $\begin{array}{c}\text { Розведення, } \\
\text { мкг/мл }\end{array}$ & Наявність росту & $\begin{array}{c}\text { Розведення, } \\
\text { мкг/мл }\end{array}$ & Наявність росту & $\begin{array}{c}\text { Розведення, } \\
\text { мкг/мл }\end{array}$ & Наявність росту \\
\hline 150 & - & 100 & - & 200 & - \\
\hline 75 & - & 50 & - & 100 & - \\
\hline 37,5 & - & 25 & - & 50 & - \\
\hline 18,7 & - & 12,5 & - & 25 & - \\
\hline 9,3 & - & 6,2 & - & 6,2 & - \\
\hline 4,7 & + & 3,1 & - & 3,1 & + \\
\hline 2,4 & + & 1,6 & + & 1,6 & + \\
\hline 1,2 & + & 0,8 & + & 0,8 & + \\
\hline 0,6 & + & 0,4 & + & 0,4 & + \\
\hline 0,3 & + & 0,2 & + & 0,2 & + \\
\hline 0,15 & + & 0,1 & + & & + \\
\hline
\end{tabular}

Примітка: «+»- наявність росту; «-»- відсутність росту

МІК досліджуваних препаратів для ізоляту Salmonella pullorum

\begin{tabular}{|c|c|c|c|c|c|}
\hline \multicolumn{2}{|c|}{ Комбінований препарат } & \multicolumn{2}{|c|}{ Монопрепарат (флуорфенікол) } & \multicolumn{2}{|c|}{ Монопрепарат (доксициклін) } \\
\hline $\begin{array}{c}\text { Розведення, } \\
\text { мкг/мл }\end{array}$ & Наявність росту & $\begin{array}{c}\text { Розведення, } \\
\text { мкг/мл }\end{array}$ & Наявність росту & $\begin{array}{c}\text { Розведення, } \\
\text { мкг/мл } \\
\end{array}$ & Наявність росту \\
\hline 150 & - & 100 & - & 200 & - \\
\hline 75 & - & 50 & - & 100 & - \\
\hline 37,5 & - & 25 & - & 50 & - \\
\hline 18,7 & - & 12,5 & - & 25 & - \\
\hline 9,3 & - & 6,2 & - & 12,5 & - \\
\hline 4,7 & - & 3,1 & - & 6,2 & - \\
\hline 2,4 & - & 1,6 & - & 3,1 & - \\
\hline 1,2 & + & 0,8 & + & 1,6 & + \\
\hline 0,6 & + & 0,4 & + & 0,8 & + \\
\hline 0,3 & + & 0,2 & + & 0,4 & + \\
\hline 0,15 & + & 0,1 & + & 0,2 & + \\
\hline
\end{tabular}

Примітка: «+»- наявність росту; «一»- відсутність росту

Значення МIК комбінованого препарату для Salmonella pullorum становить 2,4 мкг/мл. Значення МІК монопрепарату на основі флуорфеніколу становить 1,6 мкг/мл, а монопрепарату на основі доксицикліну 3,1 мкг/мл.

За значенням МІК комбінованого препарату сальмонела виявилася чутливою як до флуорфеніколу, так і до доксицикліну. Чутливим виявився ізолят Salmonella pullorum до монопрепарату на основі флуорфеніколу і помірно чутливим - до монопрепарату на основі доксицикліну. Проте, судячи з отриманих значень мінімальної інгібуючої концентрації, діючі речовини комбінованого препарату проявляють виражену синергічну дію відносно до виділеного штаму Salmonella pullorum, що проявляється підвищенням активності поєднання флуорфеніколу i доксицикліну в комбінованому препараті, порівняно з активністю цих антибіотиків у монопрепаратах.

\section{Висновки}

Доцільність розробки комбінованих антибактеріальних препаратів полягає у підвищенні антимікробної активності або розширенні спектру антимікробної дії комбінації діючих антимікробних речовин.

Діючі речовини нового антимікробного препарату, флуорфенікол і доксициклін, у комбінації проявляють індиферентну або синергічну дію відносно до мікроо- рганізмів, збудників бактеріальних інфекцій у свиней та свійської птиці.

Перспективи подальших досліджень. Актуальним залишається розробка нових комбінованих антибактеріальних засобів з широким спектром антимікробної і насамперед, синергічної дії активно діючих речовин, у першу чергу відносно до полірезистентних штамів мікроорганізмів, збудників бактеріальних інфекцій у тварин.

\section{Бібліографічні посилання}

Stetsko, T.I. (2008). Zasady efektyvnoi antybiotykoterapii u veterynarnii medytsyni. Veterynarna biotekhnolohiia. 13(1), 194-203 (in Ukrainian).

Kovalev, V.F. (1983). Puti povyshenija jeffektivnosti antibiotikov. Veterinarija. 10, 72-74 (in Russian).

Stetsko, T.I. (2008). Vzaiemodiia antymikrobnykh preparativ. Naukovo-tekhnichnyi biuleten Instytutu biolohii tvaryn i DNDKI vetprepartiv ta kormovykh dobavok. 9(4), 323-331 (in Ukrainian).

Indiveri, C., Hirsh, D.C. (1986). Sysceptibility of obligate anaerobes to trimethoprim-sulfamethoxazole. J. Am. Veter. Med. Assn. 188(1), 46-48.

Stetsko, T.I. (2005). Shliakhy pidvyshchennia efektyvnosti antybiotykoterapii. Tvarynnytstvo Ukrainy. 12, 2427 (in Ukrainian). 
Golovko, A.N., Ushkalov, V.A., Skrypnik, V.G. (2007). Mikrobiologicheskie i virusologicheskie issledovanija $\mathrm{v}$ veterinarnoj medicine. Spravochnoe posobie. Har'kov: NTMG (in Russian).

Metodychni vkazivky po vyznachenniu bakteriostatychnoi ta bakterytsydnoi kontsentratsii antybakterialnykh preparativ metodom seriinykh rozveden (zatverdzheni naukovo-tekhnichnoiu radoiu
DDVM Ukrainy Ministerstva ahropolityky Ukrainy vid 19.12.2002 r.). Kyiv, 2007, 12 (in Ukrainian).

M31-A3 Performance Standards for Antimicrobial Disk and Dilution Susceptibility Tests for Bacteria Isolated From Animals; Approved Standard - Third Edition, 2008. Vol. 24, No 8.

Стаття надійшла до редакиії 20.03.2017 